\title{
IMPROVING STUDENTS ACHIEVEMENT ON KEEPING THE INTEGRITY OF THE REPUBLIC LESSON (NKRI) THROUGH ROLE PLAY METHOD WITH COOPERATIVE LEARNING AT THE FIFTH GRADE STUDENTS IN ELEMENTARY SCHOOL NO. 25 BUKIT KECIL KECAMATAN IV JURAI
}

\author{
HUSNI
}

Volume 1 Nomor 1

JIPS ISSN: 2579-5449

\begin{abstract}
Citizenship Education (Civics) is given from elementary school to senior high school. With Civics one will have the ability to know and understand the character and culture of the nation and make citizens who are ready to compete in the international world without leaving Teak self nation. Through Civics every citizen can observe themselves with the development of information and communication technology today that gives positive and negative impacts. Civics is also useful to equip learners in order to have the ability to manage and utilize information to survive in an ever-changing, uncertain and competitive state. The research objectives are: Improving the mastery of the concept of decision-making relationship together by using props in the form of pictures and objects - objects around. Looking for information on student activeness in learning Civics about the Unitary State of the Republic of Indonesia. Describe the application method of playing a role in mod el cooperative leraning to improve learning outcomes joint decision fifth grade students of SD 25 State Small Hill District IV Jurai.

In qualitative data collection activities, observers use teacher observation sheets. Observer gives a check mark $(\sqrt{ })$ on the appearance column according to the indicator. The observations made by the observer

(observer) is about the effectiveness of the method of playing a role in improving student motivation in learning civics in particular about the material pokok the Unitary Republic of Indonesia. To get more precise data, the focus of observation is emphasized on: Teacher activity in applying role play method, Child activity in learning implementation, Student activity in role play, Indicator observed on teacher observation sheet attached. Quantitative data obtained from the results of formative test values. From these results can be to measure the success rate of learning. From the results of formative test score can be known the success rate of the use of role playing methods in improving student motivation. The quantitative data is made in accordance with the assessment guidelines that have been made by the teacher. After the teacher gives an assessment and then analyze the grain matter

The results of the study civics learning corrective action with the subject matter of the Unitary Republic of Indonesia in the first half of class V SD 25 State Small Hill District IV Jurai through cooperative learning model of learning through role-play method by effecting culture and globe props deemed sufficient. It is proven that there is an increase of learning result or evaluation result of mean value above KKM is 90 and $96 \%$ completeness level.
\end{abstract}


Keywords : cooperative learning model learning

\title{
UPAYA MENINGKATKAN HASIL BELAJAR PADA MATERI MENJAGA KEUTUHAN NKRI MELALUI METODE BERMAIN PERAN DENGAN MODEL PEMBELAJARAN COOPERATIVE LEARNING BAGI SISWA KELAS V DI SD NEGERI NO.25 BUKIT KECIL KECAMATAN IV JURAI
}

\begin{abstract}
ABSTRAK
Pendidikan Kewarganegaraan ( PKn ) diberikan sejak SD sampai SLTA. Dengan PKn seseorang akan memiliki kemampuan untuk mengenal dan memahami karakter dan budaya bangsa serta menjadikan warga negara yang siap bersaing di dunia internasional tanpa meninggalkan jati diri bangsa. Melalui PKn setiap warga negara dapat mawas diri dengan perkembangan teknologi informasi dan komunikasi dewasa ini yang memberi dampak positif dan negatif. PKn juga bermanfaat untuk membekali peserta didik agar memiliki kemampuan untuk mengelola dan memanfaatkan informasi untuk bertahan hidup pada keadaan yang selalu berubah, tidak pasti dan kompetitif. Tujuan penelitian adalah : Meningkatkan penguasaan konsep hubungan pengambilan keputusan bersama dengan menggunakan alat peraga berupa gambar dan benda - benda di sekitar. Mencari informasi keaktifan siswa dalam pembelajaran PKn tentang Negara Kesatuan Republik Indonesia. Mendiskripsikan penerapan metode bermain peran dengan model cooperative Leraning untuk meningkatkan hasil belajar pengambilan keputusan bersama siswa kelas $\mathrm{V}$ SD Negeri No.25 Bukit Kecil Kecamatan IV Jurai.

Dalam kegiatan pengumpulan data secara kualitatif, pengamat menggunakan lembar observasi guru. Pengamat memberikan tanda cek $(\sqrt{ })$ pada kolom kemunculan sesuai indikator tersebut. Pengamatan yang dilakukan oleh

metode bermain peran dalam meningkatkan motivasi siswa dalam pembelajaran PKn khususnya tentang materi pokok Negara Kesatuan Republik Indonesia. Untuk mendapatkan data yang lebih tepat, maka fokus pengamatan ditekankan pada : Kegiatan guru dalam menerapkan metode bermain peran, Aktifitas anak dalam pelaksanaan pembelajaran, Keaktifan siswa dalam pelaksanaan bermain peran, Indikator yang diamati pada lembar observasi guru terlampir. Data kuantitatif diperoleh dari hasil nilai tes formatif. Dari hasil tersebut dapat untuk mengukur tingkat keberhasilan pembelajaran. Dari hasil nilai tes formatif tersebut dapat diketahui tingkat keberhasilan penggunaan metode bermain peran dalam meningkatkan motivasi siswa. Data kuantitatif tersebut dibuat sesuai dengan pedoman penilaian yang telah dibuat oleh guru. Setelah guru memberikan penilaian lalu menganalisis perbutir soal

Hasil penelitian tindakan perbaikan pembelajaran PKn dengan materi pokok Negara Kesatuan Republik Indonesia kelas V semester I di SD Negeri No.25 Bukit Kecil Kecamatan IV Jurai melalui model pembelajaran cooperative learning melalui metode bermain peran dengan mengefektifkan alat peraga kebudayaan dan globe dipandang sudah cukup. Hal ini terbukti adanya peningkatan hasil belajar atau hasil evaluasi nilai rata - rata sudah diatas KKM yaitu 90 dan tingkat ketuntasan $96 \%$.
\end{abstract} pengamat ( observer ) adalah tentang keefektifan 


\section{Kata Kunci: model pembelajaran cooperative learning}

\section{PENDAHULUAN}

Latar Belakang masalah Pendidikan Kewarganegaraan ( PKn ) diberikan sejak SD sampai SLTA. Dengan PKn seseorang akan memiliki kemampuan untuk mengenal dan memahami karakter dan budaya bangsa serta menjadikan warga negara yang siap bersaing di dunia internasional tanpa meninggalkan jati diri bangsa. Melalui PKn setiap warga negara dapat mawas diri dengan perkembangan teknologi informasi dan komunikasi dewasa ini yang memberi dampak positif dan negatif. PKn juga bermanfaat untuk membekali peserta didik agar memiliki kemampuan untuk mengelola dan memanfaatkan informasi untuk bertahan hidup pada keadaan yang selalu berubah, tidak pasti dan kompetitif.

Pada kenyataannya, PKn dianggap ilmu yang sukar dan sulit dipahami. PKn adalah pelajaran formal yang berupa sejarah masa lampau, perkembangan sosial budaya, perkembangan teknologi, tata cara hidup bersosial, serta peraturan kenegaraan. Begitu luasnya materi PKn menyebabkab anak sulit untuk diajak berfikir kritis dan kreatif dalam menyikapi masalah yang berbeda. Sementara anak usia sekolah dasar tahap berfikir mereka masih belum formal, karena mereka baru berada pada tahap Operasi Onal Konkret ( Peaget : 1920 ). Apa yang dianggap logis, jelas dan dapat dipelajari bagi orang dewasa, kadang - kadang merupakan hal yang tidak masuk akal dan membingungkan bagi siswa. Akibatnya banyak siswa yang tidak memahami konsep PKn.

Berdasarkan temuan penulis, sebagian besar siswa kurang aktif dan berfikir kritis dalam materi Negara Kesatuan Republik Indonesia ( NKRI ). Apabila anak menghadapi masalah kontekstual baru yang berbeda dengan yang dicontohkan, anak belum mampu berfikir kritis dan menemukan solusi dengan benar sehingga banyak anak yang menjawab salah, dan dengan alasan soalnya sulit. Karena itu wajar setiap kali diadakan tes, nilai pelajaran PKn selalu rendah dengan rata - rata kurang dari KKM.

Seperti yang dialami penulis sendiri, setiap ulangan PKn nilai rata - rata anak di bawah 75. Termasuk pada materi Negara Kesatuan Republik Indonesia ( NKRI ). Nilai rata - rata formatif hanya 68. Dari 23 siswa hanya 12 siswa $52 \%$ yang memperoleh nilai 75 ke atas. Sedangkan 10 siswa yang lain $43 \%$ mendapat nilai dibawah 75 .

Menghadapi kenyataan tersebut di atas, penulis tertarik untuk mendalami dan melakukan tindakan - tindakan perbaikan pembelajaran PKn, khususnya materi Negara Kesatuan Republik Indonesia ( NKRI ) melalui penelitian tindakan kelas. Perbaikan yang penulis lakukan mengenai penerapan metode bermain peran pada materi pengambilan keputusan bersama. Harapan penulis adalah terjadinya pembelajaran aktif, kreatif dan menyenangkan serta lebih bermakna dan adanya keberanian peserta didik yang tuntas untuk menyelesaikan masalah kontektual dengan benar serta untuk lebih menguasai pelajaran.

Hipotesis yang penulis lakukan adalah dalam bentuk laporan hasil yaitu berjudul “ Meningkatkan hasil belajar Pengambilan keputusan bersama melalui metode bermain peran dengan model pembelajaran cooperative learning siswa kelas V SD Negeri No.25 Bukit Kecil Kecamatan IV Jurai “.

Berdasarkan latar belakang di atas, terdapat beberapa masalah dalam pembelajaran, sebagai berikut. a) Siswa kurang memahami konsep pengambilan keputusan bersama. b) Siswa kurang aktif dalam berdiskusi. c) Siswa kurang terampil dalam berkomunikasi dengan teman sebaya. d) Hasil belajar siswa rendah

Berdasarkan identifikasi masalah di 178 peneliti berusaha mencari faktor peny masalah dengan melakukan refleksi, bertanya kepada siswa dan melakukan diskusi dengan teman sejawat. Dari hasil diskusi dapat 
disimpulkan bahwa penyebab siswa belum memahami materi pengambilan keputusan bersama seperti berikut. a) Guru tidak menggunakan alat peraga. b) Bahwa semua siswa yang terlibat dalam pembelajaran saat melakukan diskusi hanya beberapa siswa yang aktif, sedangkan yang lain hanya mendengarkan. c) Kurangnya contoh dan latihan. d) Kurangnya bimbingan guru secara menyeluruh.

Dari analisis masalah di atas, peneliti menemukan alternatif dan prioritas pemecahan masalah sebagai berikut. a) Guru perlu menerapkan metode pembelajaran bermain peran untuk meningkatkan keaktifan siswa dalam pembelajaran PKn tentang Negara Kesatuan Republik Indonesia. b) Guru perlu memberikan contoh nyata melalui Negara Kesatuan Republik Indonesia dengan kelompok. c) Guru perlu memberikan latihan dan bimbingan secara menyeluruh pada pembelajaran PKn tentang pengambilan keputusan bersama.

\section{METODE PENELITIAN}

Tempat pelaksanaan perbaikan pembelajaran di SD Negeri No.25 Bukit Kecil Kecamatan IV Jurai. Subjek penelitian adalah siswa kelas V semester I, mata pelajaran PKn untuk materi Negara Kesatuan Republik Indonesia.

Letak SD Negeri No.25 Bukit Kecil Kecamatan IV Jurai. Keberadaannya di IV Jurai.

Jumlah siswa kelas V ada 23. Dari 23 siswa peserta didik pada awal pembelajaran hanya 12 siswa $52 \%$ yang telah mencapai KKM 75. Sedangkan 10 siswa yang lain $48 \%$ belum mencapai nilai 75 . Sebagian siswanya dari masyarakat sekitar sekolah yang memiliki tingkat ekonomi menengah sampai ke bawah. Kesadaran akan pendidikan anak kurang. Hal ini terlihat dari banyak siswa yang tidak mengerjakan tugas PR yang diberikan oleh guru. Selain itu jumlah anak yang melanjutkan ke SLTP dan SLTA juga masih sedikit.

Dalam pergaulan sehari - hari peserta didik menggunakan bahasa ibu yaitu bahasa minang dan bahasa indonesia untuk
Rumusan masalah tersebut seperti berikut. 1) Bagaimanakah keaktifan siswa dalam pembelajaran PKn tentang Negara Kesatuan Republik Indonesia? 2) "Bagaimanakah penerapan metode pembelajaran bermain peran untuk meningkatkan hasil belajar PKn tentang Negara Kesatuan Republik Indonesia di kelas V SD Negeri No.25 Bukit Kecil Kecamatan IV Jurai?"

Tujuan penelitian yang ingin dicapai adalah sebagai berikut : 1) Meningkatkan penguasaan konsep hubungan pengambilan keputusan bersama dengan menggunakan alat peraga berupa gambar dan benda - benda di sekitar. 2) Mencari informasi keaktifan siswa dalam pembelajaran PKn tentang Negara Kesatuan Republik Indonesia. 3) Mendiskripsikan penerapan metode bermain peran dengan model cooperative Leraning untuk meningkatkan hasil belajar pengambilan keputusan bersama siswa kelas V SD Negeri No.25 Bukit Kecil Kecamatan IV Jurai.

berkomunikasi baik di rumah maupun di sekolah. Akibatnya anak - anak mengalami kesulitan dalam berkomunikasi dengan menggunakan bahasa Indonesia. Bila diajak berkomunikasi siswa dapat menangkap maksud pembicaraan, namun jika diminta untuk mengungkapkan secara lisan maupun tulisan mereka mengalami kesulitan.

Waktu pelaksanaan perbaikan pembelajaran dilaksanakan dua tahap : a) Pra siklus pada hari Rabu, 26 September 2016. b) Siklus I pada hari Rabu, 3 Oktober 2016. c) Siklus II pada hari Rabu10 Oktober 2016

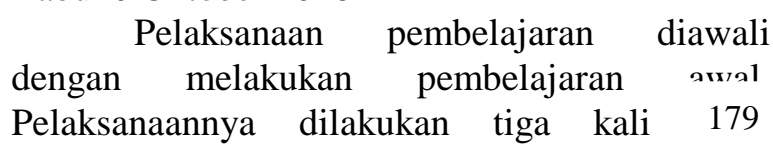
pembelajaran awal (pra siklus), siklus I

siklus II. Masing - masing terdiri darı perencanaan, pelaksanaan, pengamatan, dan refleksi dengan rincian sebagai berikut :

Perencanaan pembelajaran awal dilakukan dengan cara pembelajaran yang biasa saja tanpa ada persiapan khusus, dan dengan 
Rencana Pembelajaran (RP). Materi yang diambil adalah tentang Negara Kesatuan Republik Indonesia mata pelajaran PKn kelas V Semester I.

Rangkaian kegiatan yang dilakukan pada tahap perencanaan adalah sebagai berikut. a) Guru menyusun rencana pembelajaran dengan materi Negara Kesatuan Republik Indonesia. b) Guru menyiapkan sumber bahan dan media pembelajaran. c) Menyusun lembar kerja. d) Memilih metode diskusi kelompok. e) Membuat lembar observasi aktifitas guru dan siswa beserta indikatornya.

Pelaksanaan pembelajaran awal dilakukan selama 70 menit dalam proses pembelajaran kelas V SD Negeri No.25 Bukit Kecil Kecamatan IV Jurai. Dengan menggunakan instrument penelitian. Supervisor 2 melakukan pengamatan terhadap tingkah laku guru dalam menyampaikan materi melalui metode diskusi kelompok. Tahap pelaksanaan pembelajaran dilaksanakan seperti langkah langkah di bawah ini : a) Guru melakukan apersepsi melalui tanya jawab tentang tentang Negara Kesatuan Republik Indonesia. b) Guru menyampaikan motivasi dan tujuan pembelajaran. c) Guru menjelaskan pengertian Negara Kesatuan Republik Indonesia. d) Siswa mengerjakan lembar kerja siswa dari guru secara berkelompok. e) Perwakilan siswa maju membacakan hasil kerja kelompok f) Siswa menanggapi hasil kerja tiap kelompok dengan dipandu oleh guru. g) Siswa bersama guru menyimpulkan materi pelajaran. Siswa mengerjakan tes formatif. Guru mengoreksi hasil tes formatif. Guru memberikan tindak lanjut berupa soal perbaikan dan pengayaan dalam bentuk pekerjaan rumah. Guru menyampaikan pesan agar siswa lebih giat belajar kembali

Pengamatan dilakukan oleh Supervisor 2 , menggunakan lembar observasi yang berisi kegiatan guru, peserta didik, dan interaksi pembelajaran beserta indikator - indikatornya. Pengamatan dilakukan untuk mengetahui kekurangan dan kelebihan yang dimiliki oleh guru yang melakukan kegiatan belajar mengajar. Sehingga dapat menjadi masukan dalam melakukan kegiatan belajar mengajar berikutnya. Pengamatan didasarkan juga pada bentuk soal yaitu pilihan ganda 5 soal, isian 3 soal, dan uraian 2 soal.

Setelah melihat hasil observasi dan catatan selama pelaksanaan pembelajaran awal, guru tersebut mengadakan refleksi untuk mengetahui kekurangan, kendala, hambatan, dan kelebihan saat berlangsungnya proses pembelajaran. Karena dirasa masih banyak kekurangan dan hambatan yang menyebabkan hasil belajar siswa rendah, maka guru mengadakan perbaikan pembelajaran ke siklus I.

Pelaksanaan perbaikan pembelajaran yang dilaksanakan pada siklus I, meliputi perencanaan, pelaksanaan, pengamatan, dan refleksi. Secara lebih rinci diuraikan sebagai berikut.

Perbaikan pembelajaran siklus I dilakukan berdasarkan hasil refleksi terhadap pembelajaran awal mata pelajaran PKn di kelas $\mathrm{V}$ materi tentang Negara Kesatuan Republik Indonesia. Berdasarkan pengamatan, guru kecewa pada hasil evaluasi dari analisis nilai ditemukan bahwa dari 23 siswa hanya 12 siswa $52 \%$ yang memperoleh nilai 75 ke atas. Sedangkan 11 siswa yang lain $48 \%$ mendapat nilai dibawah 75 . Rangkaian kegiatan yang dilakukan pada tahap perencanaannya adalah sebagai berikut. Guru menyiapkan sumber bahan dan media yang akan digunakan saat pelaksanaan perbaikan silklus I. Guru menyusun rencana perbaikan pembelajaran siklus I. Guru menyusun lembar kerja siswa. Guru menyusun alat evaluasi berupa butiran soal tes formatif. Guru menyusun lembar observasi kegiatan siswa, guru, dan interaksi pembelajaran beserta indikatornya.

Pelaksanaan pembelajaran siklus I dilakukan 70 menit dalam proses pembelajaran mata pelajaran PKn kelas V SD Negeri No.25 Bukit Kecil Kecamatan IV Jurai. Denman menggunakan instrument penelitian, supervi 180 melakukan pengamatan terhadap tingkah guru dalam menyampaikan materi melaluı metode bermain peran. Tahap pelaksanaan perbaikan pembelajaran siklus I dilaksanakan seperti langkah - langkah di bawah ini : a) Guru melakukan apersepsi melalui tanya jawab dengan soal "Apa yang kalian ketahui tentang Negara Kesatuan Republik Indonesia ?" b) Guru 
menyampaikan motifasi dan tujuan pembelajaran. b) Siswa melakukan kegiatan mengambil keputusan bersama / musyawarah bersama kelompok dalam pemilihan ketua kelas. c) Siswa mengerjakan lembar kerja secara kelompok. d) Perwakilan siswa maju membacakan hasil kerja kelompok. e) Siswa menanggapi hasil kerja tiap kelompok dengan dipandu oleh guru. f) Siswa bersama guru menyimpulkan materi pelajaran. g) Siswa mengerjakan tes formatif. h) Guru mengoreksi hasil tes formatif. Guru memberikan tindak lanjut berupa soal perbaikan dan pengayaan dalam bentuk pekerjaan rumah.

Pengamatan dilakukan oleh supervisor 2, menggunakan lembar observasi yang berisi kegiatan guru, peserta didik, dan interaksi pembelajaran beserta indikator - indikatornya. Pengamatan dilakukan untuk mengetahui kekurangan dan kelebihan yang dimiliki oleh guru yang melaksanakan kegiatan belajar mengajar. Adakah peningkatan dibanding pra siklus / rencana pembelajaran awal. Sehingga dapat menjadi masukan dalam melakukan kegiatan belajar mengajar berikutnya. Pengamatan didasarkan juga pada bentuk soal yaitu pilihan ganda 3 soal, isian 2 soal, dan uraian 1 soal.

Setelah melihat hasil observasi dan catatan selama pelaksanaan pembelajaran siklus I, guru tersebut mengadakan refleksi untuk mengetahui kekurangan, kendala, hambatan, dan kelebihan saat berlangsungnya proses pembelajaran. Ternyata hasil belajar siswa masih belum memuaskan walaupun sudah ada peningkatan sedikit dan dirasa masih ada kekurangan dan hambatan yang menyebabkan hasil belajar siswa rendah maka guru mengadakan perbaikan pembelajaran pada siklus II.

Pelaksanaan perbaikan pembelajaran yang dilaksanakan pada siklus II, meliputi perencanaan, pelaksanaan, pengamatan dan refleksi. Secara lebih rinci diuraikan sebagai berikut.

Perbaikan pembelajaran siklus II dilakukan berdasarkan hasil refleksi terhadap perbaikan pembelajaran siklus I mata pelajaran PKn di kelas $\mathrm{V}$ materi Negara Kesatuan
Republik Indonesia. Berdasarkan pengamatan, guru belum puas pada hasil evaluasi dari analisis nilai ditemukan bahwa dari 23 siswa yang mendapat nilai 75 atau lebih hanya 16 siswa 69\% sedangkan yang 7 siswa $39 \%$ mendapat nilai di bawah 75 .

Rangkaian kegiatan yang dilakukan pada tahap perencanaannya adalah sebagai berikut. Guru menyiapkan sumber bahan dan media yang akan digunakan saat pelaksanaan perbaikan siklus II. Guru menyususn rencana perbaikan pembelajaran siklus II. Guru menyusun sekenario bermain peran. Guru menyusun alat evaluasi berupa butir soal tes formatif. Guru menyusun lembar observasi kegiatan siswa, guru, dan interaksi pembelajaran beserta indikatornya.

Pelaksanaan pembelajaran awal dilakukan selama 70 menit dalam proses pembelajaran mata pelajaran PKn kelas V SD Negeri No.25 Bukit Kecil Kecamatan IV Jurai. Dengan menggunakan instrument penelitian, Supervisor 2 melakukan pengamatan terhadap tingkah laku guru dalam menyampaikan materi melalui metode bermain peran. Tahap pelaksanaan perbaikan pembelajaran siklus II dilaksanakan seperti langkah - langkah di bawah ini. Guru melakukan apersepsi melalui tanya jawab dengan soal “ Bagaimana cara menjaga keutuhan Negara Kesatuan Republik Indonesia ?" Guru menyampaikan motivasi dan tujuan pembelajaran. Siswa mempraktikan kegiatan pemilihan ketua kelas melalui metode bermain peran. Semua siswa ikut terlibat dalam kegiatan pemilihan ketua kelas V. Siswa membentuk kelompok untuk mengisi lembar kerja kelompok. Perwakilan siswa maju mendemonstrasikan hasil kerja kelompok. Siswa menanggapi hasil kerja tiap kelompok dengan dipandu oleh guru. Siswa bersama guru menyimpulkan materi pelajaran. Siswa mengerjakan tes formatif. Guru mengoreksi hasil tes formatif. Guru membe 181 tindak lanjut berupa soal perbaikan pengayaan dalam bentuk pekerjaan rumah. ..... menyampaikan pesan agar siswa lebih giat belajar kembali

Pengamatan dilakukan oleh Supervisor 2 , menggunakan lembar observasi yang diisi kegiatan guru, peserta didik, dan interaksi 
pembelajaran beserta indikator - indikatornya. Pengamatan dilakukan untuk mengetahui kekurangan dan kelebihan yang dimiliki oleh guru yang melaksanakan kegiatan belajar mengajar. Adakah peningkatan dibandingkan siklus I. sehingga dapat menjadi masukan dalam melakukan kegiatan belajar mengajar berikutnya. Perlu tidakkah diadakan siklus III. Pengamatan didasarkan juga pada bentuk soal yaitu pilihan ganda 5 soal, isian 3 soal, dan uraian 2 soal.

Setelah melihat hasil observasi dan catatan selama pelaksanaan pembelajaran siklus II, guru tersebut mengadakan refleksi untuk mengetahui kekurangan, kendala, hambatan, dan kelebihan saat berlangsungnya proses pembelajaran. Ternyata hasil belajar siswa sudah cukup memuaskan yaitu ada 22 siswa $96 \%$ telah memperoleh nilai 75 atau lebih. Dengan mempertimbangkan hal itu, maka perbaikan pembelajaran tidak memerlukan siklus III. Ini berarti PTK untuk pelajaran PKn telah selesai dilaksanakan.

Teknik analisa Dalam kegiatan pengumpulan data ini, penulis dibantu supervisor 2. Pengamatan ini dilakukan pada saat berlangsungnya pelaksanaan perbaikan pembelajaran di SD Negeri No.25 Bukit Kecil Kecamatan IV Jurai. Adapun data - data yang diperoleh adalah sebagai berikut.
Dalam kegiatan pengumpulan data secara kualitatif, pengamat menggunakan lembar observasi guru. Pengamat memberikan tanda cek $(\sqrt{ })$ pada kolom kemunculan sesuai indikator tersebut.

Pengamatan yang dilakukan oleh pengamat ( observer) adalah tentang keefektifan metode bermain peran dalam meningkatkan motivasi siswa dalam pembelajaran $\mathrm{PKn}$ khususnya tentang materi pokok Negara Kesatuan Republik Indonesia. Untuk mendapatkan data yang lebih tepat, maka fokus pengamatan ditekankan pada : a) Kegiatan guru dalam menerapkan metode bermain peran aktifitas anak dalam pelaksanaan pembelajaran, Keaktifan siswa dalam pelaksanaan bermain peran Indikator yang diamati pada lembar observasi guru terlampir.

Data kuantitatif diperoleh dari hasil nilai tes formatif. Dari hasil tersebut dapat untuk mengukur tingkat keberhasilan pembelajaran. Dari hasil nilai tes formatif tersebut dapat diketahui tingkat keberhasilan penggunaan metode bermain peran dalam meningkatkan motivasi siswa.

Data kuantitatif tersebut dibuat sesuai dengan pedoman penilaian yang telah dibuat oleh guru. Setelah guru memberikan penilaian lalu menganalisis perbutir soal.

\section{HASIL PENELITIAN DAN PEMBAHASAN}

Hasil penelitian yang dilakukan pada siswa kelas V SD Negeri No.25 Bukit Kecil Kecamatan IV Jurai terkait hasil belajar PKn tentang Negara Kesatuan Republik Indonesia melalui metode bermain peran dengan model pembelajaran cooperative learning, yang dilaksanakan dalam perbaikan pembelajaran pada siklus I dan siklus II secara lengkap dijabarkan sebagai berikut.

Pembelajaran pra siklus mata pelajaran

PKn kelas V semester I di SD Negeri No.25 Bukit Kecil Kecamatan IV Jurai dengan materi pokok Negara Kesatuan Republik Indonesia dilaksanakan pada hari Rabu, 26 September 2016 hasilnya belum memuaskan.
Dari siswa yang mendapat nilai diatas 75 sebanyak 12 siswa, atau $52 \%$ sedangkan nilai kurang dari 75 sebanyak 11 siswa atau 48 $\%$ dari 23 siswa. Untuk mengetahui presentasi rentang nilai maka diadakan analisis penguasaan materi pembelajarn pra siklus bahwa dari jumlah 23 siswa yang mendapat nilai 41 sampai 50 sebanyak 2 siswa, yang mendapat nilai 51 sampai 60 sebanyak 5 siswa, nilai 61 samp 182 sebanyak 4 siswa, nilai 71 sampai 80 sebam siswa, nilai 81 sampai 90 sebanyak 3 siswa aan tidak ada yang mendapat nilai diatas 91 .

Apabila hasil evaluasi sebelum perbaikan pembelajaran PKn dengan indikator Negara Kesatuan Republik Indonesia kelas V 
semester SD Negeri No.25 Bukit Kecil Kecamatan IV Jurai .

Nilai hasil tes formatif diperoleh setelah proses pembelajaran selesai. Guru memberi evaluasi untuk mengetahui tingkat penguasaan materi yang telah diajarkan pada pembelajaran pra siklus. Adapun langkah - langkah pelaksanaan pra siklus yaitu : Membuat rencana pembelajaran, membuat lembar pengamatan, menyediakan alat peraga, membuat evaluasi, membuat lembar kerja dan menentukan teman sejawat yang akan mengobservasi aktivitas siswa dan guru selama kegiatan pembelajaran. Pelaksanaan pembelajaran pra siklus dilaksanakan pada hari Rabu, tanggal 26 September 2016, di SD Negeri No.25 Bukit Kecil Kecamatan IV Jurai. Pelaksanaan pembelajaran dilaksanaakan sesuai dengan rencana pembelajaran. Dari hasil pengamatan yang diperoleh oleh peneliti yang dibantu oleh teman sejawat sebagai observer. Berikut hasil pengamatan pada waktu proses pembelajaran pada pra siklus. Pada pra siklus ini pembelajaran berlangsung, siswa belum aktif dalam pembelajaran, siswa pada waktu diskusi kelompok belum bisa bekerja sama, waktu diberi penjelasan oleh guru ada siswa yang bermain sendiri. Sedangkan hasil pengamatan terhadap guru yaitu guru kurang menguasai materi, guru belum bisa mengontrol keaktifan siswa, guru belum menggunakan alat peraga, sehingga siswa kurang memahami struktur daun dan fungsinya.

Dari hasil refleksi yang dilakukan oleh guru melalui diskusi dengan teman sejawat sebagai observer diperoleh beberapa kekurangan selama proses pembelajaran. Sebelum pelajaran dimulai guru tidak mengkondisikan siswa untuk menerima pelajaran, sehingga siswa belum siap menerima pelajaran. Pada waktu pemberian materi guru hanya ceramah, sehingga siswa hanya menggambarkan materi NKRI itu seperti apa. Dari refleksi itu guru menyadari kekurangannya dalam proses pembelajaran oleh karena itu guru akan memperbaikinya pada perbaikan pembelajaran siklus berikutnya.

Siswa merasa senang dengan pembelajaran dengan mempelajari kubudayaan di Indonesia. Guru dapat belajar untuk menerapkan alat peraga pembelajaran. Guru dapat menjadikan alat peraga sebagai variasi model pembelajaran. Masih ada 11 siswa yang belum mencapai tingkat ketuntasan minimal. Ada beberapa siswa yang belum bisa memahami materi. Dalam menyimpulkan materi guru masih belum melibatkan siswa.

Perbaikan pembelajaran siklus I dilaksanakan pada hari Rabu tanggal 3 Oktober 2016 dengan objek siswa kelas V semester I SD Negeri No.25 Bukit Kecil Kecamatan IV Jurai. Dengan dibantu oleh teman sejawat yang bertindak sebagai observer, peneliti melaksanakan sesuai rencana. Skenario pembelajaran berlangsung dengan baik. Peneliti melaksanakan sesuai rencana. Pada akhir pembelajaran peneliti mengadakan evaluasi hasil belajar untuk mengetahui tingkat keberhasilan.

Dari tabel dapat kita lihat siswa yang mendapat nilai diatas 75 sebanyak 16 siswa, sedangkan nilai kurang dari 75 sebanyak 7 siswa dari jumlah 23 siswa. Untuk mengetahui presentasi rentang nilai maka diadakan analisis penguasaan materi sebelum perbaikan pembelajarn bahwa dari jumlah 23 yang mendapat nilai 41 sampai 50 sebanyak 2 siswa, nilai 51 sampai 60 sebanyak 5 siswa, nilai 61 sampai 70 sebanyak tidak ada, nilai 71 sampai 80 sebanyak 12 siswa, nilai 81 sampai 90 sebanyak 3 siswa dan tidak ada yang mendapat nilai diatas 91 .

Apabila hasil evaluasi perbaikan pembelajaran siklus I mata pelajaran PKn dengan indikator Negara Kesatuan Republik Indonesia kelas V semester I di SD Negeri No.25 Bukit Kecil Kecamatan IV Jurai. Hasil evaluasi siklus I diperoleh setelah pelaksanaan pembelajaran siklus I selesai. Dalam pembelajaran siklus I melalui langkah - langkah berikut. Menyusun rencana pembelajaran dengan tujuan perbaikan siklus I. Memilih metode s:111..m I. Mempersiapkan LKS yang akan digur 183 dalam perbaikan pembelajaran. Membuat merancang lembar observasi aktivitas guru beserta indikatornya.

Pelaksanaan pembelajaran siklus I dilaksanakan pada hari Rabu, tanggal 3 Oktober 2016 dikelas V. Kegiatan belajar mengajar sesuai dengan apa yang tertulis dalam rencana pelaksanaan pembelajaran. 
Pada tahap ini pengamat mencatat apa yang telah terjadi pada pembelajaran perbaikan siklus I dengan menggunakan lembar observasi. Dalam proses ini diperoleh data bahwa : Penjelasan materi sangat cepat sehingga kurang dipahami siswa. Kurang memberikan kesempatan pada anak untuk bertanya. Perhatian guru pada siswa masih kurang.

Hasil dari observasi / pengamatan dikumpulkan dan dianalisis. Dari hasil observasi guru mengadakan refleksi untuk mengetahui kekurangan, hambatan dan kendala yang terjadi pada proses pembelajaran.

Dengan dasar hasil tes formatif yang menunjukkan menunjukkan peningkatan pada pembelajaran sebelumnya, namun untuk mencapai ketuntasan $75 \%$ belum tercapai. Maka penulis mengadakan perbaikan pembelajaran tahap berikutnya yang menjadi fokus perbaikan adalah sebagai berrikut. Memberikan materi yang jelas dan lengkap sehingga mudah dipahami siswa. Memberikan kesempatan pada siswa untuk bertanya. Menggunakan model pembelajaran yang tepat.

Keberhasilan dan kegagalan pada siklus I antara lain: Hasil evaluasi belajar siswa meningkat. Sebagian besar siswa sudah memahami materi. Siswa sudah berani maju mengerjakan soal. Siswa sudah berani untuk mengajukan pertanyaan. Masih ada 7 siswa yang belum mencapai tingkat ketuntasan. Kurang memberikan kesempatan pada anak untuk bertanya. Penggunaan alat peraga kurang maksimal. Masih ada beberapa siswa yang pada saat pelajaran berlangsung masih belum bisa terlibat aktif.

Perbaikan pembelajaran siklus I dilaksanakan pada hari Rabu tanggal 10 Oktober 2016 dengan objek siswa kelas V semester I SD Negeri No.25 Bukit Kecil Kecamatan IV Jurai. Dengan dibantu oleh teman sejawat yang bertindak sebagai observer, peneliti melaksanakan sesuai rencana.

Skenario pembelajaran berlangsung dengan baik. Peneliti melaksanakan sesuai rencana. Pada akhir pembelajaran peneliti mengadakan evaluasi hasil belajar untuk mengetahui tingkat keberhasilan dapat kita lihat siswa yang mendapat nilai diatas 75 sebanyak
22 siswa, sedangkan nilai kurang dari 75 sebanyak 1 siswa dari jumlah 23 siswa.

Penguasaan materi sebelum perbaikan pembelajarn bahwa dari jumlah 23 siswa tak seorang pun yang mendapat nilai dibawah 60 , nilai 61 sampai 701 siswa, nilai 71 sampai 80 sebanyak 3 siswa, nilai 81 sampai 90 sebanyak 7 siswa dan yang mendapat nilai diatas 91 sebanyak 12 siswa.

Apabila hasil evaluasi perbaikan pembelajaran siklus II mata pelajaran PKn dengan indikator Negara Kesatuan republic Indonesia kelas V semester I di SD Negeri No.25 Bukit Kecil Kecamatan IV Jurai.

Berikut ini adalah langkah - langkah pelaksanaan perbaikan pembelajaran siklus II : Menyusun rencana pembelajaran, menentukan alat peraga, menentukan metode pembelajaran, merencanakan fokus perbaikan pembelajaran, menyusun lembar observasi, menyusun lembar evaluasi. Pelaksanaan pembelajaran siklus II dilaksanakan hari Rabu, tanggal 10 Oktober 2016, bertempat di SD Negeri No.25 Bukit Kecil Kecamatan IV Jurai.

Hasil pengamatan dari observer selama proses pembelajaran siklus II adalah siswa pada waktu menerima pelajaran memperhatikan penjelasan yang diberikan oleh guru dengan baik. Berpartisipasi dalam kegiatan pembelajaran, sudah ada keinginan untuk mencari penelesaian soal dari guru. Mau bertanya jika ada kesulitan, dan mulai berani untuk mengerjakan didepan walaupun belum bisa. Sedang pengamatan yang diperoleh observer kepada guru yang mengajar adalah guru sudah mempersiapkan rencana pembelajaran dengan baik, metode yang digunakan sudah tepat, pemberian motivasi sudah cukup tapi masih ada beberapa kekurangan tidak menanyakan kepada siswa tentang kesulita] 184 yang diperoleh dari materi yang diajarkan.

Setelah melakukan beberapa perbaınaı yaitu perbaikan pembelajaran pra siklus, siklus I dan siklus II. Peneliti menyadari betul kekurangan - kekurangan pada proses pembelajaran mata pelajaran PKn dengan materi Negara Kesatuan Republik Indonesia pada siklus II. Walaupun peneliti sudah mempersiapkan proses pembelajaran sebaik 
mungkin, tetapi tetap masih ada kekurangannya diantaranya guru kurang memberi pertanyaan kepada siswa. Dari hasil refleksi yang dilakukan tersebut teman sejawat selaku observator juga menemukan beberapa kekurangan yaitu guru tidak memberi bimbingan kepada siswa yang belum jelas atau memahami materi pelajaran.

Keberhasilan dan kegagalan pada siklus II antara lain: Hasil evaluasi belajar siswa meningkat. Sebagian besar siswa sudah memahami materi. iswa sudah berani maju mengerjakan soal. Siswa sudah berani untuk mengajukan pertanyaan.

Masih ada 1 orang siswa yang belum mencapai tingkat ketuntasan. Pengelolaan kelas masih kurang. Masih ada beberapa siswa yang pada saat pelajaran berlangsung masih belum bisa terlibat aktif.

Dari tabel pemelajaran awal sampai perbaikan pembelajaran siklus II pada mata pelajaran PKn V semester I tentang NKRI di SD Negeri No.25 Bukit Kecil Kecamatan IV Jurai, dapat disajikan pada tabel.

Berdasarkan table 4.7 dapat kita lihat bahwa pada Pra Siklus hanya 52\% siswa yang meraih ketuntasan, $69 \%$ pada siklus I dan pada Siklus II sebanyak $96 \%$ hal ini menunjukkan bahwa peningkatan yang signifikan apabila kita menggunakan metode dan cara belajar yang tepat sehingga siswa dapat belajar dengan semangat dan meraih prestasi yang kita harapkan.

Pada nilai rata - rata juga mengalami peningkatan yang signifikan, nilai rata - rata pada pembelajaran awal 68, pada siklus I mengalami peningkatan yaitu 69 dan pada perbaikan pembelajaran siklus II menjadi 96. Perbaikan pembelajaran cukup pada siklus II tidak perlu dilanjutkan pada siklus berikutnya karena tuntas dari 23 siswa ada 22 siswa atau $96 \%$ hanya 1 siswa atau $4 \%$ yang belum tuntas termasuk siswa yang lamban belajarnya.

Dari tabel 4.7 dari hasil evaluasi pembelajaran awal hingga perbaikan pembelajaran siklus II mata pelajaran matematika .

Pada gambar 4.4 menunjukkan grafik peningkatan nilai rata - rata mata pelajaran PKn dengan materi Negara Kesatuan Republik Indonesia kelas V semester I di SD Negeri No.25 Bukit Kecil Kecamatan IV Jurai, bahwa sebelum perbaikan pembelajaran nilai rata - rata 68 , pada perbaikan siklus I nilai rata - rata 69 kenaikan nilai rata - rata 1 . Pada perbaikan pembelajaran siklus II nilai rata - rata 96, kenaikan nilai rata rata dari perbaikan pembelajaran siklus I ke perbaikan siklus II yaitu 30 .

Sebelum perbaikan pembelajaran dari 23 siswa yang mengalami ketuntasan dalam belajar sebanyak 12 siswa atau hanya $52 \%$ dan 11 siswa atau $48 \%$ belum tuntas. Hal ini menunjukkan kegagalan dalam pembelajaran. Setelah penulis merefleksi diri, maka kegagalan iti disebabkan oleh beberapa hal, antara lain : Dalam penggunaan alat peraga kurang bervariasi. Pembelajaran masih didomonasi guru. Rendahnya tingkat penguasaan materi oleh siswa. Kurang relevannya metode yang digunakan.

Kegagalan dalam pembelajaran PKn dengan materi Negara Kesatuan Republik Indonesia kelas V semester I di SD Negeri No.25 Bukit Kecil Kecamatan IV Jurai, maka peneliti perlu melakukan perbaikan pembelajaran siklus I.

Berdasarkan hasil diskusi denagn teman sejawat serta supervisor bahwa ketidaktuntasan siswa dalam proses pembelajaran PKn dengan materi Negara Kesatuan Republik Indonesia kelas V semester I di SD Negeri No.25 Bukit Kecil Kecamatan IV Jurai, disebabkan oleh : Siswa kurang konsentrasi dalam pembelajaran. Tidak semua siswa terlibat aktif dalam pembelajaran. Kurangnya motivasi guru terhadap siswa. Kurangnya keberanian siswa dalam mengutarakan pendapat.

Berdasarkan temuan masalah diatas, maka langkah yang ditempuh guru untuk meningkatkan hasil belajar adalah : Meningkatkan prestasi belajar siswa dalam pengertian Negara Kesatuan Republik Indc ${ }_{185}^{\circ}$ dengan metode bermain peran.

Hal tersebut sesuai dengan teori yang dikemukakan oleh J Bruner (1966), bahwa belajar adalah suatu proses aktif yang dilakukan oleh siswa dengan jelas.

Untuk meningkatkan kreativitas dan aktivitas dalam melakukan kegiatan pembelajaran, maka pengadaan alat peraga harus ditingkatkan dengan cara : Memanfaatkan benda 
- benda yang ada disekitar siswa. Menggunakan alat peraga model kebudayaan Indonesia.

Menurut C. Roger 1969 : 9 ) dalam teori cooperative learning disebutkan bahwa proses belajar terjadi dengan adanya keterlibatan pribadi, inisiatif diri dan evaluasi diri. Teori ini menimpulkan bahwa belajar harus dilakukan oleh siswa, sedangkan guru hanya sebagai fasilitator. Maka pemilihan metode demonstrasi sangatlah tepat untuk meningkatkan prestasi belajar siswa. Meningkatkan keberanian siswa dalam mengutarakan pandapat melalui pendekatan model cooperative learning.

Pendekatan cooperative eraning akan memberikan kesempatan pada anak untuk memiliki keberanian dalam mengutarakana pendapat. Dalam hal ini diharapkan tutor sebaya mampu membimbing temannya dalam melakukan percobaan. Hal ini sesuai denagn pendapat Siberman $(2000 ; 157)$ bahwa mengajar teman sebaya (per teaching) merupakan salah satu cara untuk mematangkan penguasaan siswa terhadap suatu pelajaran tertentu.

Dalam pelaksanaan mengajar teman sebaya, fungsi guru lebih difokuskan sebagai fasilitator dan motivator untuk memberikan penguatan. Hal tersebut sesuai dengan pendapat Brammer (1979;42) yaitu hubungan yang bersifat membantu merupakan upaya guru untuk menciptakan iklim pembelajaran yang kondusif akan terjadinya pemecahan masalah dan pengembangan diri peserta didik.

Berdasarkan hasil refleksi tindakan perbaikan pembelajaran pada siklus I dihasilkan antara lain : Tutor sebaya belum terampil menggunakan alat peraga untuk membimbing temannya dalam melakukan pembelajaran

\section{KESIMPULAN DAN SARAN}

Setelah peneliti melaksanakan perbaikan pembelajaran melalui pembelajaran siklus I dan siklus II dengan materi Negara Kesatuan Republik Indonesia dikelas V semester I di SD Negeri No.25 Bukit Kecil Kecamatan IV Jurai, maka penulis dapat mengambil kesimpulan bahwa upaya meningkatkan prestasi belajar siswa dengan metode bermain peran melalui tentang kebudayaan. Masih ada beberapa siswa yang ragu dan tidak terlibat aktif dalamn melakukan demonstrasi. Guru memberi pengarahan agar siswa terlibat aktif dalam melakukan bermain peran. Dalam diskusi kelompok, masih ada beberapa siswa yang aktif dan kurang kerja sama dalam menyelesaikan tugas. Hasil evaluasi siswa masih banyak yang rendah, masih ada 7 siswa yang nilainya dibawah KKM dan tingkat ketuntasan kelas $69 \%$. Dengan demikian maka tindakan perbaikan dilanjutkan pada siklus II.

Adapun hasil refleksi pada siklus II adalah: Tutor sebaya sudah terampil menggunakan alat peraga untuk membimbing temanya dalam mempelajari kebudayaan. Hampir semua siswa terlibat aktif dalam melakukan bermain peran. Dalam diskusi kelompok, hampir semua siswa sudah aktif dan tercipta kerja sama yang baik dalam menyelesaikan tugas. Hasil evaluasi belajar sudah baik walaupun masih ada 1 siswa yang nilainya dibawah KKM. Namun rata - rata nilai sudah diatas KKM yaitu 90 dan tingkat ketuntasan $96 \%$.

Dengan demikian tindakan perbaikan pembelajaran PKn dengan materi pokok Negara Kesatuan Republik Indonesia kelas V semester I di SD Negeri No.25 Bukit Kecil Kecamatan IV Jurai melalui model pembelajaran cooperative learning melalui metode bermain peran dengan mengefektifkan alat peraga kebudayaan dan globe dipandang sudah cukup. Hal ini terbukti adanya peningkatan hasil belajar atau hasil evaluasi nilai rata - rata sudah diatas KKM yaitu 90 dan tingkat ketuntasan $96 \%$

pendekatan model cooperative learning dengan mengefektifkan alat peraga kebudayaan dan globe telah mampu meningkatkan hasil belajar siswa.

Peningkatan ini terjadi pada sil 186 maupun siklus II dengan bukti a peningkatan pada : 1) Menggunakan media pembelajaran kebudayaan dan globe dapat 
meningkatkan pemahaman siswa terhadap materi Negara Kesatuan Republik Indonesia. 2) Model pembelajaran cooperative learning melalui penerapan metode bermain peran untuk dengan mengefektifkan alat peraga dapat meningkatkan hasil belajar siswa. 3) Prosentase ketuntasan belajar siswa mengalami peningkatan yang signifikan setelah dilakukan perbaikan pembelajaran pada evaluasi sebelum perbaikan pembelajaran ada 12 siswa atau 52\% dari 23 siswa. Pada perbaikan pembelajaran siklus I meningkat, siswa yang nilainya 75 keatas menjadi 16 atau 69\% dari jumlah 23 siswa dan pada perbaikan siklus II menjadi 22 siswa atau $96 \%$.

Saran tindak lanjut berdasarkan pengalaman peneliti selama melaksanakan Penelitian Tindakan Kelas untuk meningkatkan prestasi belajar siswa SD Negeri No.25 Bukit Kecil Kecamatan IV Jurai peneliti kemukakan saran dan tindak lanjut sebagai berikut. Guru sebaiknya mengusahakan media pembelajaran benda - benda konkret yang berada disekitar siswa dapat menghilangkan verbalisme dan menyenangkan. Guru harus memberi motivasi dan bimbimngan pada siswa yang mengalami kesulitan. Guru hendaknya menciptakan suasana belajar yang menyenangkan. Di era kompetisi siswa perlu dilatih untuk berani mengemukakan pendapat oleh karena itu latihan membimbing kawan - kawannya dalam melakukan bermain peran merupakan ajang latihan yang cukup kreatif. Siswa perlu dilatih untuk bergaul dan bekerjasama yang harmonis dalam kelompoknya denagn kegiatan yang positif. Oleh karena itu bekerja dalam kelompok untuk menyelesaikan tugas tertentu merupakan cara yang efektif untuk melatih sifat social pada siswa. Laporan ini dapat dijadikan bahan kajian untuk meningkatkan pengetahuannya melalui forum KKG dll.

\section{DAFTAR PUSTAKA}

Andayani, dkk. 2010, Pemantapan Kemampuan Profesional. Jakarta, Universitas Terbuka.

Aswani, Zaenul,2004, Tes dan Asesmen di SD, Jakarta, Universitas Terbuka.

Denny, Setyawan, 2005, Komputer dan Media Pembelajaran, Jakarta, Universitas Terbuka.

Gatot, Muhsetyo, Drs. M.Sc, dkk, 2007, Pembelajaran PKN, Jakarta, Universitas Terbuka.

Mulyani Sumantri, Nana Syaodih. 2007. Perkembangan Peserta Didik. Jakarta, Universitas Terbuka.
Samsudin, Abin, 2004, Profesi Keguruan 2, Jakarta, Universitas Terbuka.

Suciati, Drs. Dkk, 2004, Belajar dan Pembelajaran 2, Jakarta, universitas Terbuka.

Wardani, I.G.A.K, 2008, Penelitian Tindakan Kelas, Jakarta, Universitas Terbuka.

Wahyudi Duin, Supaiyati, Ishak, Abduhak, 2001, Pengantar Pendidikan, Jal 187 Universitas Terbuka.

Dra. Dyah Sriwilujeng, M.Pd, Buku PKn untuk SD Kelas V, Jakarta, Esis.

Pranaja S dkk, Buku Fokus PKn untuk SD Kelas V, Jakarta, Sindutama. 